\title{
A Review on Responses of Potato to Macro and Micro Fertilizers Application
}

\author{
Egata Shunka Tolessa \\ Ethiopian Institute of Agricultural Research, Holleta Agricultural Research Center, Crop Research Process, \\ Potato Research Program, Addis Ababa, Ethiopia
}

\begin{abstract}
Potato was considered as food security crop in Ethiopia because of its high yielding potential, high nutritional quality, short growing period and wider adaptability. In area coverage, it is second widely grown crop next to 'Enset' (Ensete ventricosum L.). Its production is affected by many factors. Among these factors, optimum fertilizer application is the main factor degrading the productivity of the crop. Achieving optimum fertilizer application depends on the climate, soil, variety and availability of the water. This review was aimed to access all available fertilizer trials to point out the types of fertilizers soil is deficient in relation to potato crop response and needed additional application during production cycles for boosting yield. Almost all soil of arable lands of Ethiopia was deficient in nitrogen $(\mathrm{N})$, phosphorus $(\mathrm{P})$, and sulfur(S). In addition, a larger part of arable land was deficient in N, P, S, and boron (B). Some lands' soils require addition of either of potassium or Zinc other time both. Potato is requiring both macro and micro elements for high yield and better quality product. It is concluded that, most reviewed sources indicate that there was less recommendation concerning micro and macro elements for potato in the country in relation to the variable ecology of the country owned.
\end{abstract}

DOI: $10.7176 / \mathrm{ALST} / 87-05$

Publication date: April $30^{\text {th }} 2021$

\section{Introduction}

Potato (Solanum tuberosum $L$ ) is classified under family solanaceae, genus solanum, and series Tuberosa (Van den Berg and Jacobs, 2007). It is originated in the Andes of South America and cultivated for the first time in the border of Peru and Bolivia (Horton, 1987). It was introduced to Ethiopia before 163 years ago by the German botanist Schimper (Pankhurst, 1964). Since then, its production grew gradually from high land garden lands to the field crop status in high land and mid land mainly in rain fed and in lesser land under irrigation production systems. Now, it is important food security crop in many parts of the country. On global scale, there was a production volume of 368 million metric tons annually from an estimated area of 17.58 million hectares (FAOSTAT, 2018). Potato has become an important crop in many parts of Ethiopia and it ranks first among root and tuber crops in volume produced and consumed followed by Cassava, Sweet potato and Yam (CSA, 2017). It was considered as food security crop in Ethiopia because of its high yielding potential, high nutritional quality, short growing period and wider adaptability (Tewodros et al., 2014 and Brasesco et al., 2019). In area coverage it is second widely grown crop next to 'Enset' (Ensete ventricosum L.)(Girma, 2001).

Potato has been highly recommended by the Food and Agriculture Organization (FAO) as a food security crop. Potato helped smallholder farmers by providing direct access to nutritious food, increasing household incomes and minimized their danger to face the food price instability (André et al., 2014). In Ethiopia, its meher season production area has reached about 70,362.22 ha, with total production of 924,528.361 cultivated by over 1.068 million households (CSA, 2019). On the other hand, the productivity of this crop in the country is very low (13.14 $\mathrm{t} \mathrm{ha}^{-1}$ ) compared to the world's average yield of $19 \mathrm{t} \mathrm{ha}^{-1}$ (CSA, 2019). According to Brasesco et al. (2019), model farmers those using full technology (good quality seeds and optimum fertilizer application accompanied with good agronomic practice) potato yield showed that a yield potential up to $50 \mathrm{t} / \mathrm{ha}$. Balanced fertilization applications sustains optimal crop production, better quality product and ensues profitability of growers. Nutrients such as N, P, K, S, B, Zn and Fe are plant nutrients found deficient in Ethiopian cultivable land soil though there are variation among location types and included in new fertilizer formula of the Ethiopian soils. In area coverage most soils are deficient in N, P, S, and B followed by those location lacking N, P, and S (EthioSIS, 2016) and in general all cultivated land soils lack N, P and S. According to EthioSIS(2016), the soil content of different elements were said deficient whenever each of them was below 30, 190, 20,0.5, 0.9, and 0.8 ppm foe P, K, S, Zn, Cu, and B, respectively based on the soil critical point concept. Fertilizers application based on crop needs and soil deficiency, reduce soil nutrient imbalance and satisfy crop needs, improve crop productivity and reduce poverty. Fertilizer rates determination and recommendation should base on climate, soil factors, and crop needs. In Ethiopia, research works carried earlier have been limited to the two common macronutrients $(\mathrm{N}$ and $\mathrm{P}$ ) for long time that resulted in soil nutrient imbalance and degrade soil ecology which in turn greatly influence sustainable harvestable yield.

Based on the crop needs and soil shortages new fertilizing materials with secondary and micronutrients would be required to ensure balanced fertilizer use involving most of the nutrients required by crops (Bewketet 
al., 2018). That is why many fertilizer formula such as NPS, NPSB, NPSFeB, NPSFeZn, NPSFeBZn, NPSZn, NPSB, NPKSB, NPKSFeB, NPKSFeZn, NPKFeZnB, NPKSZn and NPKSZnB and soon are developed in the country based on soil shortage and crop needs (EthioSIS, 2015). Not only developing the formula but also the availability and cost of the fertilizers also play significant role in utilization of the developed technology and converting the opportunity for improving productivity and reducing poverty. One of the problems of our farmers facing now is a problem similar to these mentioned ones. There is developed formula but some of them are not available in the amount required and the available ones are high cost while some are available but there is less attention to utilize them. This review was conducted to collect available information about fertilizers effect on potato crop and indicate the gap for researchers and users.

\subsection{Origin, Botany and Ecology of potato}

The origins of potato can be traced backs to the highlands of the Peruvian Andes-mountains in South America on the border between Bolivia and Peru, 8,000 years ago. Research indicates that communities of hunters and gatherers, who had first entered the South America continent at least 7,000 years ago, before domesticating wild potato plants that, grew around the lake in abundance. It was in the central Andes that farmers succeeded in selecting and improving the first of what was to become, over the following millennia, a staggering range of tuber crops. In fact, what we know as "the potato" (Solanum tuberosum L) contains just a fragment of the genetic diversity found in the seven recognized potato species and 5,000 potato varieties still grown in the Andes. Potatoes have relatively shallow, fibrous root system with the majority of the roots in the surface $30 \mathrm{~cm}$. The root system develops rapidly during early growth and achieves maximum development by midseason. Thereafter, root length, density and root mass decrease as the plant matures. Rooting depths of $1.2 \mathrm{~m}$ or more have been reported for potato under favorable soil conditions (Tanner et al., 1982).

The main stem of the potato plant terminates in flower cluster. They bear white, pink, red, blue, or purple flowers with yellow stamens. Flower bud abortion may occur at a very early stage of development; but in any case apical growth of the main stem ceases with formation of the flower buds. The cessation of growth of the main shoot axis may not be obvious because sympodial growth of one or more axillary branches just below the apex permits further extension above the flower (Rending and Taylor, 1989.).

\subsection{Climatic Requirements of Potato}

Potato grows well and produces yields at an altitude of over 1000 meters above sea level, although recently produced cultivars perform well at low elevations ranging from 400 to 2000 meters above sea level in tropical highlands (Levy and Veilleux, 2007). In Ethiopia, the altitude between 1800 to 2500 meters above sea level is regarded as suitable for seed and potatoes production (Bezabih and Mengistu, 2011). Potato is grown in many different environments, but it is best adapted to temperate climates (Hijmans, 2003). Higher temperatures above $29^{\circ} \mathrm{C}$ diminish tuberization, promote foliage growth and reduce partitioning of photosynthate and assimilate to the tubers (Levy and Veilleux, 2007). Potato is also frost sensitive and severe damage may occur when temperature drops below $0^{\circ} \mathrm{C}$ (Hijmans, 2003). Short day length and low temperatures are principally important to enhance tuber initiation and the number of tubers formed (Levy and Veilleux, 2007).

Potato is basically a crop of temperate region, but there is a large variation in the gene pool with respect to its response to thermo periods. The rate of development of sprouts from seed pieces depends on soil temperature. Very little sprout elongation occurs at $6^{\circ} \mathrm{C}$; elongation is slow at $9^{\circ} \mathrm{C}$ and is maximized at about $18^{\circ} \mathrm{C}$. The optimum soil temperature for initiating tubers is $16-19^{\circ} \mathrm{C}$ (Anonymous, 2003). ). The number of tubers set per plant is greater at lower temperatures than at higher temperatures, whereas a higher temperature favors development of large tubers. Yields are highest when average daytime temperatures are about $21^{\circ} \mathrm{C}$ (Anonymous, 2003). Cool night temperatures are important because they affect the accumulation of carbohydrates and dry matter in the tubers. At lower night temperatures, respiration is slowed, which enhances storage of starch in the tubers (Anonymous, 2003). Farmers have also developed a frost resistant potato species that survives on the alpine tundra of the Puna zone at 4,300m.a.s.1 (14,100ft.) (Gebremedhin et al., 2008). Better tuber yields have been obtained from potatoes grown at soil reaction ranging from pH 5.2 to 6.5 (Fageria et al., 2011). According to FAO (2000) report the $\mathrm{pH}$ range of most crops were 4-8 because of variable optimum $\mathrm{pH}$ requirement of different crops. Optimal soil pH for potato is indicated as 5 to 5.5(Ann et al., 2017).

\subsection{Distribution of Potato in the World}

The global distribution of potato is described using country-level statistics and a new geo-referenced data base. There are two main peaks in global potato distribution by latitude. The major peak is between $45^{\circ} \mathrm{N}$ and $57^{0} \mathrm{~N}$ and represents potato production zones in the temperate climate where potato is a summer crop. The other peak is between $23^{\circ} \mathrm{N}$ and $37^{\circ} \mathrm{N}$, and mainly presents production those in the subtropical lowlands, where the crop grows in winter crop. Between 1950 and 1998, potato production area increase at low latitudes and decreased at high latitudes, particularly around $53^{\circ} \mathrm{N}$ (this zone includes parts of Belarus, Germany, Poland Russia, and 
Ukraine). The northern limit of potato production coincides with the boundaries of agriculture and the presence of human population density (per area of land and per area of arable land). About $25 \%$ of the global potato area is in the highlands above 1000 m.a.s.l. (American Journal of Potato Research, 2001).

\subsection{Major Potato Production Area in Ethiopia}

In Ethiopia, potato is grown in four major areas: the Central, the Eastern, the North-Western and the Southern regions, which together constitute approximately $83 \%$ of the potato farmers in the country (CSA, 2008). In the Central area, potato production includes the highland areas surrounding the capital city of Ethiopia, Addis Ababa. In this area the major potato growing zones are West Shewa and North Shewa. About $10 \%$ of the potato farmers are located in this area (CSA, 2008). Average productivity of a potato crop ranges from 8 to 10 ton ha ${ }^{-1}$ which is higher than the productivity in the North-Western and Southern areas. This higher productivity might be due to the use of improved varieties and practices obtained from Holetta Agricultural Research Centre in the central area. In the central area potato is produced mainly in the belg (short rain season-February to May) and meher (long rain season-June to October) periods. Potato is also grown off-season under irrigation (October to January). Because of the cool climate and access to improved varieties, farmers in this area of the country also produce seed potatoes which are sold to other farmers in the vicinity or to NGOs and agricultural bureaus to be disseminated to distant farmers. In the central area, farmers grow about seven local varieties, eight improved varieties and six clones i.e. genetic material which is not officially released (Adane et al., 2010).

\subsection{Economic Importance of Potato}

Potato serves as food and cash crop for small scale farmers and occupies the largest area compared to other vegetable crops and produces more food per unit area and time compared to cereal crops (Tesfaye et al., 2015). As a food crop, it has a great potential to supply high quality food within a relatively short period and is one of the cheapest sources of energy. Moreover, the protein from potato is of good composition with regard to essential amino acids in human nutrition (Hussain, 2016). Relatively high carbohydrate and low fat content of potato makes it an excellent energy source for human consumption. It is known to supply carbohydrate, high quality protein and a substantial amount of essential vitamins, minerals and trace elements (MoARD, 2011). The potato production area is rapidly expanding due to its high yield potential and suitability hence, it is estimated that potato is cultivated at about one hundred thousand hectares before 2001 (Endale and Gebremedhin, 2001) while it was more than 296 thousand hectors in 2016 production season(CSA, 2017).

\subsection{The Current Status of Potato Production in World and Ethiopia}

FAO (2008) reported that potato is one of the world most important crops and consumed for more than 8,000 years. The annual world potato production is estimated to 376 million tons (FAOSTAT, 2015). Among this, Asia and Europe are the major potato producing continents, which cover more than $80 \%$ of the world production. Today, China is the biggest potato producer in the world which covered about $25 \%$ of world production (FAOSTAT, 2015). In recent time, Algeria is the biggest potato producer in Africa which is estimated to 5 million tons in 2013 (FAOSTAT, 2015). Kenya is the biggest potato producer in East Africa with a total production of about 2.2 million tons while Kenya, potato is the second most important crop following maize (FAOSTAT, 2015). Here it is cultivated by about 500,000 smallholders, making it one of the most important sources of income and employment in rural areas (Obare et al. 2010). In Ethiopia, according to Gebremedhin et al.(2008), the major potential areas for potato production are the Central, Southern, Southeastern, Southwestern and Northwestern part of the country, where altitude ranges from 1500 to $3000 \mathrm{~m}$ and the annual rain fall between 600 to $1200 \mathrm{~mm}$. Potato is produced in the belg (short rain season-February to May) and meher (long rain season June to October) periods. Potato is also grown off-season under irrigation (October to January) in Ethiopia.

Potato is one of the tuber crops growing in Ethiopia. It is grown by approximately 1,197,018 farmers (CSA, 2017). Among African countries, Ethiopia has possibly the greatest potential for potato production (Firew et al., 2016). At present, potatoes are still widely regarded as a secondary crop, and annual per capital consumption is estimated at $5 \mathrm{~kg}$. The production of potato is expanding at a faster rate than other food crops in developing countries, including Ethiopia. The crop has also proved that it has great potential for adaptation to the diverse growing conditions of the tropics where the majority of the developing countries are located.

\subsection{Major Constraints to Potato Production in Ethiopia}

Potato production like other crops is affected by both biotic and abiotic stresses. Biotic factors affecting potato production and productivity include; insect pests, bacteria, fungi and viruses. The abiotic agents limiting potato production include low soil fertility, inadequate moisture supply, stress due to high temperatures and drought. The national average potato yield is very low as compared to the potential yield (50 t ha-1) obtained under research conditions and model farmer's situations. This is due to narrow genetic basis of potato varieties, poor 
seed quality, susceptibility to diseases and poor farmers' management practices including soil fertility and nutrient management problems (Haverkort et al., 2012; Tewodros, 2014). On the other hand, not exploiting available water, limited the productivity of potato crop though the country is wealthy in its available irrigation water and irrigable land. Moreover, the crop is better performing under irrigation than the main cropping season due to disease influence exclusion and getting easy workable soil which favor the crop and management operations during cultivation and earthing up.

\subsection{Opportunities of Potato production in Ethiopia}

Ethiopia has suitable condition for potato production and potato can play an important role in improving food security and cash income of small hold of potato growers in Ethiopia. As a food crop, potato has a high potential to supply a cheap and quality food within a relatively short period. There is a high potential to expand the cultivation area of the potato crop in Ethiopia. Not only expanding cultivation land but also exploiting other system of production like irrigation is also crucial as the land is free of cropping off-season and potato is best performing due to escaping of highly devastating late blight diseases. While, national average yields are still far below attainable yields, ample opportunities exist to utilize this crop's potential for increasing food security and income generation in Ethiopia (Helen, 2016).

Agronomic practices in most of the potato growing areas of Ethiopia leave much to desire for improvement. The agro-ecologies where farmers thrive to grow potato are characterized by diverse conditions. They vary considerably in soil type, moisture and temperature regimes, fertility conditions, and in the on-set, intensity and duration of rain. Therefore, crop management operations have to take into account of these differences to ensure high yielding potential of cultivars. In general, several activities were conducted so far on various agronomic practices to improve the production and productivity of potato in different parts of the country. However, some of these research recommendations were obsolete and should be revised for enhancing the yield of the crop. Therefore, the research and development on agronomic practices of potato should be continued to improve the production and productivity of potato as a food security crop in the country (Abebe et al., 2016).

\subsection{Effects of Mineral Nutrients on Growth and Yield of Potato}

In the past years, mineral fertilizer was advocated for crop production to ameliorate low inherent fertility of soils in the tropics. However, currently it is well recognized that the use of mineral fertilizer has not been helpful in intensive agriculture because it is often associated with reduced crop yield, soil acidity and nutrient imbalance (Kumar et al., 2013). Appropriate mineral fertilizer application, especially nitrogen and phosphorus are required to correct the nutrient imbalance in infertile soils (Peter et al., 2015). Potatoes require high quantity of nutrients in order to form abundant vegetative mass and high quantity tubers per unit area (White et al., 2007). Moreover, potatoes require high amounts of fertilizer due to the characteristics of shallow and inefficient rooting system (Dechassa et al., 2003). Potatoes respond to an ample soil moisture supply with an increase in yield and quality (Dolores et al.,2009). A rainfall ranging between 500 and $750 \mathrm{~mm}$ with even distribution during the growing period is generally necessary for optimum growth (Stol et al.,1991). Potatoes have relatively shallow root zone and lower tolerance for water stress compared to other crops, therefore irrigation may be required where rainfall is limited (Makani et al., 2013). Fayera (2017) confirmed that increasing the rate of nitrogen increase total tuber yield/plot average tuber weight, marketable tuber weight, unmarketable tuber weight, total tuber number/ plant and small tuber size. In agreement with this, finding of Biruk (2018) reported increasing the rate of nitrogen from 0 to $92 \mathrm{Kg} / \mathrm{ha}$ linearly increased shoot dry biomass yield. Application of 165 $\mathrm{kg} \mathrm{N} /$ ha increased shoot dry weight from 52.75 to 72.25 by $19.5 \mathrm{~g} /$ hill compared to control (Israel et al., 2012). Minwyelet (2017) report that the application of NPS fertilizer at the rate of $272 \mathrm{~kg} /$ ha produced the highest total tuber yield (47.53 $\mathrm{t} / \mathrm{ha})$, while potato plants without NPS fertilizer produced the lowest total tuber yield (17.32 $\mathrm{t} / \mathrm{ha}$ ). In agreement with this report, increasing NPS application rates significantly increased marketable tuber yield of potato (Melkamu and Miniweyilet, 2018).

\subsubsection{Nitrogen}

Agricultural crops have a considerable dependence on inorganic nitrogen and 85-90 million metric tons of nitrogenous fertilizers are added to the soil worldwide annually. Due to the cost associated with manufacture, nitrogen is one of the most expensive nutrients to supply and commercial fertilizers represent a major cost in potato crop production. Nitrogen is a key element in potato growing and required by the plant's roots and shoot throughout the growing season. Nitrogen gas makes up $80 \%$ of the earth's atmosphere, but this gaseous nitrogen is unavailable for plant growth. Bacteria play an essential role in making atmospheric $\mathrm{N}$ available for plant growth. Nitrogen is a very dynamic plant nutrient and inefficient utilization by plants that may result in environmental pollution (Moreno et al., 2003). It is an essential component of proteins, nucleic acids and enzymes. Along with magnesium, it is a major constituent of chlorophyll, the green colored compound that traps sunlight and utilizes the solar energy to manufacture the products required for growth and development. Pale green new leaves, yellowing of older leaves, slow growth and stunted growth, are likely symptoms of nitrogen 
deficiency (Foth and Ellis, 1997). Potato plants have a high requirement for nitrogen to produce the amount of protein required by the leaves, roots and tubers. Potato plant roots can take up several chemical forms of nitrogen. The most common are ammonium $\left(\mathrm{NH}_{4}{ }^{+}\right)$, nitrate $\left(\mathrm{NO}_{3}{ }^{-}\right)$and urea $\left(\left(\mathrm{NH}_{2}\right) 2 \mathrm{CO}\right)$. Natural processes in the soil can convert one form into another. The nitrogen in urea is completely water-soluble. Upon application, urea nitrogen changes rapidly to $\mathrm{NH}_{3}-\mathrm{N}$ which is readily available to plants on application to the soil (Kolbe et al., 1997).

Urea is the most widely used dry nitrogen fertilizer in the world. After application to soils, urea is converted into ammonia, which can be held in the soil or converted into nitrate. Ammonia volatilization following fertilization with urea can be substantial, and if urea is applied to the surface of the land, without immediate incorporation into the soil, considerable loss of nitrogen can occur (Truog, 1946). Hydrolysis of urea by urease produces ammonium carbonate. With surface-applied urea, alkalinity of $\mathrm{pH} 9$ or higher can develop under the urea granule or pellet, and ammonia will volatilize into the air. Volatilization occurs on bare ground, on debris, or on plant leaves. Urea is readily soluble in water, and rainfall or irrigation after its application will move it into the soil and lessens volatilization losses. Use of urease inhibitors has been suggested to lessen the volatilization losses of ammonia from surface-applied urea. Manufactured urea is identical to urea in animal urine. Currently there is considerable interest in the efficient use of $\mathrm{N}$ in agriculture (Wikipedia, 2016)).

An adequate supply of $\mathrm{N}$ is associated with vigorous vegetative growth and a dark green color while an unbalanced $\mathrm{N}$ and higher $\mathrm{N}$ rates are associated with more foliage, promoted photosynthetic action and translocation to tubers (Kumar et al., 2007). However, an excess of this nutrient in relation to other nutrients, such as $\mathrm{P}, \mathrm{K}$, and $\mathrm{S}$ leads to excessive stolen and leaf growth, delayed leaf maturation, tuber differentiation, extended tuber bulking period, and ultimately reduced yield and tuber dry matter (Goffart et al., 2008). Whereas shortage of $\mathrm{N}$ restricts the growth of all plant organs, roots, stems, leaves, flowers, stunted plant growth, yellowing leading to low fruits and seed yields (Barker and Bryson, 2007). Shortage of $\mathrm{N}$ also restricts tuber size due to reduced leaf area and early defoliation (Goffart et al., 2008).Nitrogen is very important nutrient in potato production as the value of the other inputs cannot be fully realized unless $\mathrm{N}$ is applied to the crop in an optimum amount (Ruža et al., 2013). Several N fertilization rates have been advised as optimal rate for potato production. In some European countries and the USA that have a potato growth cycle of 4-5 months, the recommended N fertilization rates vary from 70 to $330 \mathrm{~kg}$ ha-1, and the most economically efficient rates range from 147 to 201 $\mathrm{kg}$ ha-1 (Fontes et al., 2010). Researchers in the Czech Republic advice application of fertilizer rate of $140 \mathrm{~kg}$ ha-1 as the optimal to obtain tuber yield above 30 t ha-1 (Ruža et al., 2013).

Many factors and processes including initial amount of mineral N, net mineralization or immobilization, denitrification, leaching, and atmospheric deposition influence the relation between nitrogen supply and uptake (Ruža et al., 2013). Furthermore, according to Vos (1997), all factors that affect the depth of root penetration (density and texture of soil, $\mathrm{pH}$, etc.) or its function (including pests, diseases, drought and water logging) also affect the relationships between supply and uptake. Potato is a crop that is highly responsive to N-fertilizer (Sincik et al., 2008). Therefore, the nitrogen rate identification was difficult due to these mentioned problems and the sources applied to the soil. Now days, there are two nitrogen sources applied to soil in highlands used for potato growing (Urea and NPSB). The nitrogen needs of crops may vary when the source vary which necessitate the response assessment for different varieties of potato. In line with this, rate determinations for nitrogen should be done related to climate, time of application, the source, soil matrix and varietal reaction.

\subsubsection{Phosphorus}

\subsubsection{Phosphorus in Soils and Plants}

Plants absorb phosphorus in the form of $\mathrm{HPO}_{4}{ }^{-2}$ and $\mathrm{H}_{2} \mathrm{PO}_{4}^{-}$(Tisdale et al., 1995). The physical and chemical properties of soils were reported to influence the solubility of phosphorus and its adsorption reactions in soils. These include the nature and amount of soil minerals, soil pH, cation effect, anion effect, extent of phosphorus saturation, reaction time and temperature, flooding and fertilizer management (Tisdale et al., 1995). Moreover, availability of phosphorus from fertilizers may be affected by the soil reaction, the degree of soil phosphorus deficiency, rate and method of application, needs of the specific crops, certain soil differences. The maximum availability of phosphorus for plant utilization is known to occur at soil $\mathrm{pH}$ between 6.5 and 7.5.

The use of phosphorus fertilizers becomes imperative because the concentration of phosphorus in many soils is reported to be very low and it is also liable to different chemical reactions that make it unavailable to plants. Plants provided with adequate amount of phosphorus have been reported to form good root system, strong stem, mature early and give high yield. On the other hand, plants grown on phosphorus deficient soils show stunted growth, low shoot to root ratio, poor fruit and seed formation, purple colored leaves with reddish discoloration of the stem. Biochemically, phosphorus deficiency causes changes in functions of the plant including accumulation of sucrose and reducing sugars and sometimes of starch(Tisdale et al., 1995).

\subsubsection{The role of phosphorus in potato cropping}

Agriculture and food production are dependent on a $\mathrm{p}$ supply to produce adequate food, fiber and fuel for society (Hopkins et al., 2008; Syers et al., 2008). Efficient use of $\mathrm{P}$ is also crucial in order to minimize losses of $\mathrm{P}$ from agro-ecosystems (Syers et al., 2008; Hart et al., 2004). The fact that p losses from agriculture contribute to 
eutrophication of aquatic ecosystems further emphasizes the importance of efficient agronomic P use (Syers et al., 2008; Bergström et al., 2007).

\subsubsection{Phosphorus Requirements of Potato}

The need for $\mathrm{p}$ is critical during the early stage of growth when normal meristem development and rapid vine growth are necessary for a high yield. Large amounts of $\mathrm{p}$ are needed for starch phosphorylation in potatoes. Tubers from 50 -day-old plants contained only $23 \%$ of the total plant $\mathrm{p}$; while tubers from plants 123 days old contained $83 \%$ of the total plant $\mathrm{p}$ (Houghland, 1960). On soils containing sub-optimum levels of available $\mathrm{p}$, potato crops show economic responses to the application of $\mathrm{P}$ fertilizer (Johnston et al., 1986) and, as a result, relatively large amounts are applied in commercial practice. Surprisingly, very few studies have attempted to analyze the mechanism by which this nutrient influences crop growth although some reports have suggested that adequate levels of P promote early leaf canopy growth but may advance senescence (Dyson and Watson, 1971). Such responses might be expected to influence the temporal patterns of radiation interception, and thereby dry matter accumulation under varying conditions of $\mathrm{p}$ supply.

Potato cultivars differ in the extent and duration of their canopy growth (Griffith et al., 1984). Whilst adequate nutrient levels are necessary to maintain an active canopy for an extended period, the amounts required may vary between cultivars as a consequence of intrinsic variation in their capacity to generate leaf area. Consequently, the response to applied P fertilizer may vary if the principal effect of this nutrient is to influence canopy cover. Cultivars also vary in the depth and density of their root growth (Allen and Scott, 1992). Those with a more limited root system, a characteristic usually associated with earlier maturing cultivars, have a reduced capacity to explore the soil profile for nutrients. This is particularly important for those nutrients that are relatively immobile in soil, such as $p$, for which uptake is limited to depletion zones that are very close to the root surface (Wild, 1988). Factors other than cultivar influence rooting and, therefore, the likely response to fertilizer P seed sprout status as well-sprouted seed generally produce smaller leaf canopies (O'Brien et al., 1983) and are likely also to have more shallow rooting systems, although substantial evidence to support this is lacking.

\subsubsection{Phosphorus acquisition in potato}

Phosphorus is taken up by the potato crop continuously over the growing season. However, the amount taken up per day varies depending on the phenological stage. Although $\mathrm{P}$ is crucial, the element is needed in relatively small amounts, $0.5 \mathrm{~kg}$ ton-1 compared with $3 \mathrm{~kg}$ ton-1 for $\mathrm{N}$ and $4 \mathrm{~kg}$ ton-1 for K (Stark et al., 2004; Dampney et al., 2002; Bennett, 1993). The report of (Girma et al., 2017) indicated that increasing phosphorous rate increases marketable tubers, total tuber numbers, average tuber weight were highly increased due to high responsive of potato as compared to other tuber crops. As the recommended amount of $\mathrm{P}_{2} \mathrm{O}_{5}$ was $90 \mathrm{~kg} / \mathrm{ha}$ for highland of Ethiopia regardless of the variety and soil components, it has to be checked again and again as it is related to cost and nutrient is depleting and depleting with time due to continues cropping and leaching as well as erosion. On the other hand, previous recommendation was done on DAP as p-source and due to soil nutrient change blended fertilizer which contain nitrogen, phosphorus, sulfur and Boron was recommended as p-source for some highland like Holetta; In different chemical formula which can vary the needs of crop. Therefore, it is important to evaluate the variety responses to the different rates of NPSB blended fertilizer and recommend economically optimum rate for production.

\subsubsection{Role of Sulfur on the growth and yield of potato}

Sulfur is classified as a secondary element, along with Magnesium and Calcium, but it is sometimes called "the $4^{\text {th }}$ major nutrient. Some crops can take up as much P as S. Sulfur is one of the key secondary elements essential for optimal plant growth. It is taken up from the soil solution by the plant in the sulfate form $\left(\mathrm{SO}_{4}{ }^{2-}\right)$. Sulfur is one of sixteen essential nutrient elements and fourth major nutrient after NPK, required by plants for proper growth and yield as it is known to take part in much reaction in all living cell (Sud and Sharma, 2002) and sulfur deficient plant had poor utilization of nitrogen, phosphorus and potash and a significant reduction of catalyze activities at all age (Nasreen et al., 2003). Effect of sulfur application on quality parameters of potato after harvesting was studied by many authors. Jaiswal et al., (2008) and Ullah and Saikia (2008) reported differences in quality parameters among different varieties of potato. According to these authors, tuber yield per plant showed maximum values with $45 \mathrm{~kg}$ ha-1 Sulfur which was significantly superior over control, 15 and $30 \mathrm{~kg}$ ha1 sulfur application. Mani et al.,(2014) small size tuber yield (\%) was the maximum under control followed by 15 , 30,60 and $45 \mathrm{~kg}$ ha-1 in descending order along with this medium and large size tuber yield (\%) was maximum under $45 \mathrm{~kg}$ ha-1 followed by 60,30 and $15 \mathrm{~kg}$ ha-1 sulfur. Sud and Sharma (2002) reported that increase in tuber yield with increasing sulfur levels may be attributed to its role in better partitioning of the photosynthesis in the shoot and tubers. Significant effect on grade wise tuber yield and increase in bulking rate with sulfur application was reported by Lalitha et al., (2002). Most soils of Ethiopia was found short of sulfur, so that blended fertilizer like NPSB and NPS was formulated for such soils and the need of crops grown for food on this soil has to be accessed on the base of yield and yield component traits. According to Bewket et al.,(2018), increasing the rates of sulfur resulted in to significant total tuber and marketable yield increased probably because of sulfur effect on the synthesis of sulfur containing amino acids, proteins, energy transformation, and activation of enzymes. 


\subsubsection{Boron}

Boron is an essential micronutrient for plants, and plant requirements for this nutrient are lower than the requirements for all other nutrients except molybdenum and copper. It is the only non-metal among the micronutrients and also the only micronutrient present over a wide $\mathrm{pH}$ range as a neutral rather than an ion (Epstein and Bloom, 2005). Boron has been found to play a key role in reproductive processes affecting anthers development, pollen germination and pollen tube growth (Loomis and Durst, 1992). Besides, Kaisher et al. (2010) reported a synergistic effect while working on sulfur and boron with respect to yield and yield contributing characters in addition to quality of the crop yield. Boron deficiency can be confused with Ca deficiency, which also affects the growing points and leads to their 'dying off.' Ca deficiency also causes leaf necrosis, which is seen at the edge of the leaf and not between the veins as with boron deficiency. Potato has a relatively low requirement hence deficiency symptoms occurs mainly on soils with poor boron content (weathered sandy soils) or soils with a high fixing capacity (recently limed, peat soils, pH > 7) (Kolbe, 1997). Some of the symptoms of boron deficiency in potato appear as a chlorosis in the interveinal areas of new leaves, leaf and plant growth stunting, death of leaves and fall of the plant (Raskshya and Arjun, 2019).The primary role of boron is in the cell walls, where it provides cross links between polysaccharides to give structure to cell walls. Boron also plays roles in formation of sugar complexes for translocation within plants, and in the formation of proteins (Truog, 1946). Boron deficiency induces thickening of the young leaves also crinkled and bordered by light brown tissue, which extends to the intercoastal areas. The growing points and the shoot tips die off. In severe cases, the leaf margins are cupped upward (Kolbe, 1997). Deficiency symptoms are induced by sandy soils, alkaline soils and soils low in organic matter, high levels of nitrogen, and high levels of calcium, cold wet weather, and periods of drought. Boron is important for improved crop development and improved tuber quality. It reduces incidence of internal Rust Spot and incidence of internal browning (Truog, 1946). Due to these reasons, the micro nutrient blended form of fertilizer developed in the country when soil was found deficient in Boron and the need for the rate determination for Blended fertilizer that contain boron become one area of work for researchers in Ethiopia. Not only rate determination but also the variety effect evaluation in relation to their boron requirement is also basic information to be obtained. Boron application also significantly increased tuber yield probably due to its role in regulation of carbohydrate metabolism and its transport within the plant besides the synthesis of amino acids and proteins(Walter and Rao, 2015). Furthermore, crops differ in their micronutrient contents depending on species, variety and physiological features (Oury et al., 2006). Among the important factors regulating the crop nutrient supply, the root system temperature, fluctuations of plant physiological processes are consequently, control the plant nutrient supply (Baghour, 2002).

\subsubsection{Potassium effect on potato}

Potassium was found increasing both marketable and total tuber weight by increasing tuber sizes (Shunka et al., 2016). On an average, potato removed about $91 \mathrm{kgK} 2 \mathrm{O}$ ha-1 at the yield of $29 \mathrm{Mg}$ ha-1 (Moinuddin et al., 2005). Duan et al. (2013) found that the average uptake of $\mathrm{K}$ by rain fed potato and irrigated potato in Inner Mongolia of China was 82.2 and $221.7 \mathrm{kgK} 2 \mathrm{O}$ ha-1 at the yield of 14.9 and $35.7 \mathrm{Mg}$ ha-1, respectively. The positive effect of $\mathrm{K}$ fertilization is greater on tuber quality than on yield (Kavvadias et al., 2012). The commonly used methods for $\mathrm{K}$ recommendations for crops are based on soil testing and sometimes can be used effectively for guiding fertilizer applications (Hannan et al., 2011), but the critical level of soil test K should be determined. The alternative way is to make fertilizer recommendation based on yield response and agronomic efficiency, which was successfully used in fertilizer recommendation for wheat and maize (Chuan et al., 2013; Xu et al., 2014). Another method for $\mathrm{K}$ recommendation is based on $\mathrm{K}$ balance in soil plant systems and the recommended rate of $\mathrm{K}$ should be at least the amount of K removed by crop products (Shutian et al., 2015). Similarly, nutrient uptake by the potato crops also depends on the climatic condition, soil type and fertility status, variety cultivated and crop management practice (Sedera and Shetata, 1994)). Potassium (K) aids in maintaining osmotic potential which enhances water uptake and root permeability, control ionic balances, regulate plant stomata and activate enzymatic processes(Bishwoyog and Swarnima, 2016). According to Bishwoyog and Swarnima (2016) potassium $(\mathrm{K})$ plays significant role in quality as well as yield attributes of potato such as reducing sugar, Vitamin C content, specific gravity, shelf life and total yield. Because of higher loss and low replacement of potassium, widespread deficiency of potassium have been reported in many of the intensively cultivated soil(Adhikary and Karki, 2006) and application of K fertilizers have responded satisfactorily (Regmi et al.,2002). Potassium is one of the most essential nutrients required for plant development. It plays vital role in several physiological processes such as photosynthesis, translocation of photosynthates, control of ionic balance, regulation of plant stomata and transpiration, activation of plant enzymes and many other processes (Thompson, 2010). The quality parameters such as dry matter, specific gravity, starch contents, vitamin-C and ash contents are affected with application of $\mathrm{P}$ and $\mathrm{K}$ (Khan et al., 2012). Application of Potassium is not only responsible to increase $\mathrm{K}$ concentration but also affects the concentration of $\mathrm{N}$ and $\mathrm{P}$ in potato tubers (Muhammad et al., 2015). According to Singh and Lal (2012) potassium significantly affect plant height, number of leaves per plant and marketable yield of potato tubers. Application of Potassium fertilizer plays vital role in yield of potato. Such 
increases in yield of potato tubers are either due to the formation of large size tubers or increasing of the number of tubers per plant or both. Westennann (2005) stated that insufficient K resulted in smaller-sized tubers. Potassium increases the size but not the total number of tubers (Trehan et al., 2001). Potassium helps to increase the content of carbohydrate significantly which ultimately helps to increase the tuber size (A-Moshileh \& Errebi, 2004). Compared to other vegetables commonly found in grocery stores, potatoes are the largest and most affordable source of potassium (Drewnowski et al. 2013) with zero mg of sodium per serving, and $2 \mathrm{~g}$ of fiber. In human case, Accordding to Bethke and Jansky(2018),potassium control high blood pressure and decrease risk of strock when taken in high amount. The adequate intake of potassium for adult peoples was 4,700mg per day which is $100 \mathrm{~g}$ boiled potato can supply $16 \%$ of this requirement.

\subsubsection{Zinc effect on potato}

According to the Food and Agriculture Organization (FAO), about 30\% of the cultivable soils of the world contain low levels of plant available Zn (Hafeeze et al., 2013)]. Zinc is an important micro-nutrient needed for good growth and performance of potato (Raskshya and Arjun, 2019). Zinc exerts a great influence on basic plant life processes, such as: Nitrogen metabolism and uptake of nitrogen, photosynthesis and chlorophyll synthesis (Tahmorespour et al., 2013). Genotypes were variable in the concentration of mineral elements (copper, iron, manganese, zinc) in potato tubers (Subramanian et al., 2017 and Asrat et al., 2018). Potatoes are an excellent candidate for tackling malnourishment in developing countries and easily satisfying micronutrient needs of fast growing global population. According to Raskshya and Arjun (2019), folar application of Zn significantly affected the potato height, stem number, canopy coverage and tuber yield. The mineral composition of potato was improved by foliar application of $\mathrm{Fe}$ and $\mathrm{Zn}$ by $\mathrm{Fe}(+70 \%)$ and $\mathrm{Zn}(+27 \%)$ over the control (Anita et al., 2020) and they recommended $200 \mathrm{~g}$ serving of potatoes for one day dietary need of micro nutrient.

$\mathrm{Fe}$ and $\mathrm{Zn}$ facilitate the functioning of different enzymes, including DNA/RNA polymerases, Nmetabolizing enzymes and numerous other enzymes involved in redox processes (Broadley et al., 2012). In sugar beet (Barłóg et al.,2016) there was Zn treatments significant impact on total uptake of $\mathrm{N}$ and significant positive correlation between tuber Zn and N concentration(White et al., 2012). According to Buono et al. (2009) potato tubers are source of vital minerals like potassium in higher amount and lesser amount of magnesium, phosphorus, manganese, zinc and iron. These essential elements are nutritionally important which play critical roles in various biological processes of both plants (Maathuis, 2009) and human beings (Martinez-Ballesta et al., 2010). In humans, the deficiencies cause metabolic disorders and organ damage, leading to acute and chronic diseases and even death (Dos et al., 2013). Its deficiency is worldwide common problem and the most important global challenges for human nutrition (Pinto et al., 2015). Over three billion people are currently malnourished, with the highest rates in developing countries where iron $(\mathrm{Fe})$, zinc $(\mathrm{Zn})$ and vitamin $\mathrm{A}$ are the most critical deficiencies (Gabriela et al., 2007). According to Renata et al. (2020), balanced micronutrient supply is the prerequisite to ensure normal plant growth no less than the supply of essential macronutrients. In the plant metabolism, the mutual proportions between the individual macro and micronutrients are of greater importance than the absolute element contents (Fageria et al., 2008). According to Renate et al. (2020), there was significant effect of zinc applied with sulfate potassium in the variety bred for crisps. Zinc effected $52 \%$ protein content (Zhang et al., 2008).

\subsubsection{Iron effect on potato}

Iron element is found to be increasing tuber yield from 40-45 \% (Renata et al., 2020). According to Gabriela et al. (2007) application of Iron resulted in yield increases of potato though some research indicated that there is considerable variation among genotypes in the concentration of mineral elements (copper, iron, manganese, zinc) in potato tubers (Subramanian et al., 2017 and Asrat et al., 2018). In line with this, Gebriela et al. (2021), reported significantly different Iron concentration of potato with variety, location and variety interaction environment. Micronutrients fertilization improved mineral composition of raw potatoes (Anita et al., 2020). According to Broadley et al. (2012), Fe (Iron) involved as facilitator of different enzymes, including DNA/RNA polymerases, N-metabolizing enzymes and numerous other enzymes. Potato is a good source of vitamin C, vitamin B6 and iron (Buono et al., 2009). Food is the best means of getting Iron in human beings. More than three billion people are reported to be malnourished with the greater amount in developing countries especially iron (Fe) and vitamin A are the most critical deficiencies (Gabriela et al., 2007). Iron deficiency weaken physical growth, cognitive development, immunity and poor school performance in young children, while in pregnant women, it causes fetal growth retardation and is responsible for a large proportion of maternal deaths (Gabriela et al., 2007).

\subsection{Concussion}

Potato is responsive to both micro and macro element application. It is highly productive and a food security crop of the Ethiopian peoples. Achieving optimum fertilizer application is important agronomic activities that encourage the crop to provide the yield to its maximum potentials. Almost all Ethiopian soils is in generally deficient in macro element $\mathrm{N}, \mathrm{P}$, and $\mathrm{S}$ while some of the locations lack micro elements $\mathrm{B}, \mathrm{Zn}$ as well as macro 
element P. It is concluded that, most reviewed sources indicate that there was less recommendation concerning micro and macro elements for potato in the country in relation to the variable ecology the country owned

\section{Reference}

Abebe Chindi, Gebremedhin W/Giorgis, Daniel Mekonnen, Amsalu Ayana, 2016. Review of Potato Agronomic Research in Central highlands of Ethiopia: Achievements and Future Prospects, Vol.51, 2016.

Adane Hirpha, M.P.M. Meuwissen, Agajie Tesfaye, W.J.M. Lommen, A.O. Lansink, AdmasuTsegaye, and P.C. Struik, 2010. Analysis of seed potato systems in Ethiopia. American potato journal. 87:537-552.

Adhikary, B. H., \& Karki, K. B. 2006. Effect of potassium on Potato Tuber Production in Acid Soils of Malepatan, Pokhara. Nepal Agriculture Research Journal, 7.

Allien, E.J., and R.K. Scotts, 1992 Principles of agronomy and their application in the potato industry. P 817-88.

Al-Moshileh, A. M., \& Errebi, M. A. 2004. Effect of Various Potassium Sulphate Rates on Growth, Yield and Quality of Potato Grown under Sandy Soil and Arid Conditions. Potassium and Fertigation development in West Asia and North Africa (pp. 24-28). Rabat, Morocco: IPI Regional Workshop.

American Potato Journal, 2001.The effect of time of planting on occurrence of internal brown spot in potato variety, Arran Banner in Lebanon. American Potato Journal.37:23-27.

André, D., Peter, K. and Oscar O., 2014. Potatoes for Sustainable Global Food Security European Association for Potato Research, 57 (3-4): pp.185-199.

Anita Ierna , Alessandra Pellegrino , Rosario Paolo Mauro and Cherubino Leonardi ,2020. Micronutrient Foliar Fertilization for the Biofortification of Raw and Minimally Processed Early Potatoes. Agronomy 2020, 10, 1744; doi:10.3390/agronomy10111744.

Ann McCauley, Clain Jones, MSU and Kathrin Olson-Rutz, 2017. Soil pH and Organic Matter. Nutrient Management Module No. 8.

Anonymous, 2003. Guide to Commercial Potato Production on the Canadian Prairies published by the Western Potato Council.

Arega Made, 2018. Response of Potato (Solanum tuberosum L.) to blended NPS and Potassium Fertilizers

Asrat, A.; Woldegiorgis, G.; Kolech, S.A.; Mulugeta, G.; Mulugeta, D.; Ngugi, A.; Burgos, G.; Felde, T.; Bonierbale, M, 2018. Micro-nutrient composition and end-user acceptable quality in potato in Ethiopia. Acta Agric. Scand. Sect. B Soil Plant Sci. 2018, 68, 596-607.

Baghour, M.; Moreno, D.A.; Hernández, J.; Castilla, N.; Romero, L, 2002. Influence of root temperature on uptake and accumulation of $\mathrm{Ni}$ and Co in potato. J. Plant Physiol. 2002, 159, 1113-1122.

Barłóg, P.; Nowacka, A.; Błaszyk, R, 2016. Effect of zinc band application on sugar beet yield, quality and nutrient uptake. Plant Soil Environ. 2016, 62, 30-35.

Bennett WF, 1993. Plant nutrient utilization and diagnostic plant symptoms. In: Nutrient Deficiencies and Toxicities in Crop Plants, Bennett WF.(Editor).American Phytopathological Society1-7.

Bergastrom, L., Djodjic, F., Kirchmann, H., Nilsson, I. and Ulen, B, 2007.Phosphorus from farmland to water. Report Food 4, 63.

Bethke P, Jansky S, 2018. The Effects of Boiling and Leaching on the Content of Potassium and Other Minerals in Potatoes. J Food Sci 73(5):H80-H85

Bewket Getachew Bekele, Derbew Belew and Tesfaye Abebe, 2018. NPSZnB Fertilizer and Cattle Manure Effect on Potato (Solanum tuberosum L.) Yield and Yield Components in Awi Zone, Ethiopia. International Journal of Soil Science, 13: 35-41.DOI: 10.3923/ijss.2018.35.41.

BezabihEmana and MengistuNigussie, 2011. Potato value chain analysis and development in Ethiopia.International Potato Center (CIP-Ethiopia), Addis Ababa, Ethiopia.

Biruk Nimena, 2018. Effects of blended NPSB and Nitrogen fertilizers on Yield and yield components Potato ( Solanum tubersum L).

Bishwoyog Bhattarai, Swarnima K.C, 2016. Effect of Potassium on Quality and Yield of Potato Tubers - A Review . SSRG International Journal of Agriculture \& Environmental Science (SSRG - IJAES ) 3( 6): https://www.researchgate.net/publication/329414830.

Brasesco, F., Asgedom, D., Casari, G, 2019. Strategic analysis and intervention plan for potatoes and potato products in the Agro-Commodities Procurement Zone of the pilot Integrated Agro-Industrial Park in CentralEastern Oromia, Ethiopia. Addis Ababa, FAO. 80 pp. Licence: CC BY-NC-SA 3.0 IGO.

Broadley, M.; Brown, P.; Cakmak, I.; Rengel, Z.; Zhao, F, 2012. Functions of nutrient: Micronutrients. In Marschner's Mineral Nutrition of Higher Plants, 3rd ed.; Marschner, P., Ed.; Elsevier: Oxford, UK, 2012; pp. 243-248.

Buono, V.; Paradiso, A.; Serio, F.; Gonnella, M.; De Gara, L.; Santamaria, P, 2009. Tuber quality and nutritional components of early potato subjected to chemical haulm desiccation. J. Food Compos. Anal. 2009, 22, 556-562.

Burtukan Belachew, 2016. Effect of nitrogen and phosphorus rates on growth, yield, yield components and 
quality of potato( Solunum tuberosum L).

Chuan, L., He, P., Pampolino, M.F., Johnston, Jin, J., Xu, X., Zhao, S., Qiu, S., Zhou, W, 2013. Establishing a scientific basis for fertilizer recommendations for wheat in China: yield response and agronomic efficiency. Field Crops Res. 140, 1-8.

CSA, 2008. Agricultural sample survey: Report on area and production of crops, Addis Ababa, Ethiopia. 126p.

CSA (Central Statistical Agency), 2008. Report on Area and Production of Crops. Unpublished Agricultural Index Survey Report, Addis Ababa, Ethiopia.

CSA(Central Statistical Agency), 2017. Agriculteral sample survey: Report on area and production of crops, Addis Ababa, Ethiopia.

CSA, 2019. Agricultural Sample Survey Report on Area and Production (Private Peasant Holdings Meher Season. Central Statistical Agency of Ethiopia, Statistical Bulletin

Dampney, P., Johnson, P., Goodlass, G.,Dyer, C. and Sac, A.S, 2002. Review of the response of potatoes to phosphate. DEFRA project PE0108, 52.

Dechassa, N., Schenk, M.K. and Steingrobe, N, 2003. Phosphorus efficiency of cabbage (Brassica oleraceae L. var. capitata), carrot (Daucuscarota L.), and potato (Solanum tuberosum L).Plant and Soil, 250: pp.215224.

Drewnwski A, 2013. New metrics of affordable nutrition: which vegetables provide most nutrients for least cost? Journal of the Academy of Nutrition and Dietetics 113:1182-7.

Dolores, M., Torres, A., Parreno, W.C, 2009.Thermal processing and quality optimization.In Advances in potato chemistry and technology (pp. 163-219).

Dos Santos, I.F.; dos Santos, A.M.; Barbosa, U.A.; Lima, J.S.; dos Santos, D.C.; Matos, G.D, 2013 Multivariate analysis of the mineral content of raw and cooked okra (Abelmoschus esculentus L.). Microchem. J. 2013, $110,439-443$

Duan,Y., Tuo, D., Zhao, P., Li,H., Li, S, 2013.Response of potato to fertilizer application and nutrient use efficiency in Inner Mongolia. Better Crops 97, 24-26.

Dyson, P. W and D. J. Watson, 1971.Analysis of the effect of nutrient supply on the growth of potatoes. Annual of Applied Biology. 69:47-63.

Endale, G. and Gebremedhin, W.G, 2001. Effects of Spatial Arrangement on Tuber Yields of Some Potato Cultivars. African Crop Science Journal, 9(1): pp.67-76.

Epstein, E. and Bloom, A.J, 2005. Mineral Nutrition of Plants: Principles and Perspectives. 2nd Edition, Sinauer Associates, Inc., Sunderland.

EthioSIS, 2016. The role of DSM in transforming agriculture: The case of Ethiopian soil information system pp. 35.

FAOSTAT(Food and Agricultural Organization Static protocols s), 2018. Crop production Data, Available online at http://faostat.fao.org.

FAOSTAT, 2015. Data base of agricultural production. Food and Agriculture Organization, Rome, Italy.

Fageria, N.K.; Baligar, V.C.; Li, Y.C, 2008. The role of nutrient efficient plants in improving crop yields in the twenty first Century. J. Plant Nutr. 2008, 31, 1121-1157.

Fageria, N.K., Baligar, V.C. and Jones, C.A, 2011. Growth and Mineral Nutrition of Field Crops 3 Edition., Taylor \& Francis Group. Available at: http://www.crcpress.Com, (Accessed on August 2015).

Fayera, 2017. Yield and yield components of potato (Solanum tuberosum L.) as influenced by planting density and rate of nitrogen application.

Firew Gebremariam, Nigussie Dechassa and Wassu Muhamed, 2016. Response of potato (solanum tuberosum L.) to the application of mineral nitrogen and phosphorus under irrigation in Dire Dawa, Eastern Ethiopia. Journal of Natural Sciences Research. ISSN 2224-3186 (Paper) Vol.6, No.7, 2016.

Fontes, P. C. R., Braun, H., Bussato, C., Cecon, P. R, 2010. Economic optimum nitrogen fertilization rates and nitrogen fertilization rate effects on tuber characteristics of potato cultivars. Potato Res., 53, 167-179.

Foth, H.D. and Ellis, B.G, 1997. Soil fertility.2nd ed. Lewis Publisher, CRC Press, New York.

Gebremedhin, W., Endale, G., and Berga, L. 2008. Potato seed management. In Root and Tuber Crops: The Untapped Resources. (Eds.) Gebremedhin Woldegiorgis, Endale Gebre and Berga Lemaga. Ethiopian Institute of Agricultural Research (EIAR). ISBN: 978-99944- 53-19-1. Pp. 53-77.

Gebriela Burgos, P. Sosa, C. Chacaltana, L. Muñoa, M. Scurrah, E. Salas, R. Ccanto, F. Díaz, T.z. Felde, 2020. Iron concentration of potato and sweetpotato clones as affected by location Journal of Agriculture and Food Research, https://doi.org/10.1016/j.jafr.2021.100100.

Gebriela Burgos, Amoros W, Morote M, Stangoulis J, Bonierbale M, 2007. Iron and zinc concentration of native Andean potato varieties from a human nutrition perspective. J Sci Food Agric 87(4):668-675.

Girma A, 2001. Influence of nitrogen and phosphorus on yield, yield components and tuber quality of two potatoes on Nitosols in Bako area. An MSc thesis presented to School of Graduate Studies of Alemaya University. pp 112. 
Girma, Ch., Abebe, C., and Zeleke, O, 2017. Response of applied phosphorus fertilizer rate and plant spacing for potato (Solanum tuberosum L.) production on nitisols in central highland of Ethiopia. Greener Journal of Agricultural Sciences, 7, 255-262. doi: 10.15580/GJAS.

Griffith, R. L. E.J. Allen, S.A.O' Brien and P.J.O'Brien, 1984. Comparison of growth and early yields of potato varieties of contrasting maturity classification at three sites. Journals of agricultural science 103: 443-458.

Goffart, J.P., Olivier, M. and Frankinet, M, 2008. Potato crop nitrogen status assessment to improve Nfertilization management and efficiency: Past-present-future. Potato Research, 51: pp.355-383.

Hafeez B, Khanif YM, Saleem M, 2013. Role of zinc in plant nutrition- A Review. American journal of experimental agriculture 3(2): 374-391.

Hannan, A., Arif, M., Ranjha, A.M., Abid, A., Fan, X.H., Li, Y.C, 2011. Using soil potassium adsorption and yield response models to determine potassium fertilizer rates for potato crop on a calcareous soil in Pakistan. Commun. Soil Sci. Plant Anal. 42, 645-655.

Hart,M.R., Quin, B.F. \& Nguyen, M, 2004a. Phosphorus runs off from agricultural land and direct fertilizer effects. Journal of environmental quality 33(6), 1954-1972.

Haverkort, A.J., Koesveld, M.J., van Schepers, H.T.A.M., Wijnands, J.H.M., Wustman, R. and Zhang, X.Y, 2012. Potato prospects for Ethiopia: on the road to value addition. Lelystad: PPO AGV, 2012 (PPO publication 528), 66p.

Helen Tesfaye, 2016. A reviews on Potato (Solanum uberosum L.) production Situations in EthiopiaVol.57, 2016, pp34.

Hijmans, R.J.,2003. The effect of the climate change on Global Potato Production .

Hopkins, B.G., Rosen, C.J., Shiffler, A.K. and Taysom, T.W., 2008. Enhanced efficiency fertilizers for improved nutrient management: potato (Solanum tuberosum L) Crop Management Online at http://www. Plant management network.org.

Horton, 1987.Potato production, Marketing and programs for developing countries. West view Press, London pp. 235

Houghland, G.V.C, 1960.The influence of phosphorus on the growth and physiology of the potato plant. America potato Journal37:127-138.

Hussain, T, 2016. Potatoes: Ensuring Food for the Future. Advances in Plants \& Agriculture Research. Department of Plant Pathology, IARI, India. Proceedings, 3 Issue 6.

Israel Zewide, Ali Mohammed and Solomon Tulu, 2012.Effect of different rates of nitrogen and phosphorous on yield and yield components of potato (Solanum tuberosum L.).International Journal of Soil Science, 7(4): pp.146-156.

Jaiswal, R. K., Nandekar, D. N., and Rajni, N, 2008. Performance of processing cultivars of potato in satpura zone of Madhya Pradesh. In Proceedings of the Global Potato Conference, Dec (pp. 9-12).

Johnston A.E., P. W. Lane, G. E. G. Mattingly, P.R poulton and M.V Hewitt, 1986. Effects of soil and fertilizer $\mathrm{P}$ on yields of potatoes, sugar beet, barley and winter wheat on a sandy clay loam soil at saxmundham, Suffolk. Journal agricultural science 106: 155-167.

Kaisher MS, Rahman MA, Amin MHA, Amanullah ASM and Ashanullah ASM, 2010.Effect of sulphur and boron on the seed yield and protein content of mungbean.Bangladesh Res. Pub. J. 3:pp.1181-1186.

Kavvadias, V., Paschalidis, C., Akrivos, G., Petropoulos, D, 2012. Nitrogen and potassium fertilization responses of potato (Solanum tuberosum) cv. Spunta. Commun. Soil Sci. Plant Anal. 43, 176-189.

Khan, M. Z., Akhtar, M. E., Mahmood-ul-Hassan, M., Mahmood, M. M., \& Safdar, M. N, 2012. Potato tuber yield and quality as affected by rates and sources of potassium fertilizer. Journal of Plant Nutrition., 35(5), 664-677.

Kolbe H., Stepha-Beckmann, S, 1997. Development, growth and chemical composition of the potato crop (Solanum tuberosum L.). I. leaf and stem. Pot. Res. 40:111.

Kolbe H., Stephan-Beckmann S, 1997, Development, growth and chemical composition of the potato crop. II. Tuber and whole plant. Potato Res., 40, 135-153.

Kumar, R., and J. Singh, 2003. Regional water management modeling for decision support inirrigated agriculture. J. Irrig. Drain. Eng. ASCE 129:432-439.

Kumar, P., Pandey, S.K., Singh, B.P., Singh, S.V. and Kumar, D, 2007. Effect of nitrogen rate on growth, yield, economics and crisps quality of Indian potato processing cultivars. Potato Research, 50: 143-155.

Kumar, C.V., Prakash, S.S., Prashantha, G.M., Mahendra, K.M.B., Lohith, S.and Chikkaramappa, T, 2013.Dry matter production and yield of potato as influenced by different sources and time of fertilizer application and soil chemical properties under rainfed conditions. Research Journal of Agricultural Sciences, 4(2): pp.155159 .

Lalitha, B. S., Nagaraj, K. H., T. N, 2002. Effect of source propagation, level of potassium and sulphur on potato (Solanum tuberosum L.). Mysore Journal of Agriculture Science, 36(2): 148-153

Levy, D. and Veilleux, R.E, 2007.Adaptation of potato to high temperatures and salinity.A review. American 
Journal of Potato Research, 84: pp.487-506.

Loomis and Durst, 1992. Proceeding of an international workshop on all aspects of animal and plant boron nutrition, held July 23-27, in Bonn, Germany.

Maathuis, F.J, 2009. Physiological functions of mineral macronutrients? Curr. Opin. Plant Biol. 2009, 12, 250258.

Makani, J., Ofori-Acquah, Nnodu, O.,Wonkam,A. and Ohene-Frempong, 2013. Sickle Cell Disease: New Opportunities and Challenges in Africa. Department of Hematology and Blood Transfusion, Muhimbili University of Health and Allied Sciences, P.O. Box 65001, Dar es Salaam, Tanzania.

Martinez-Ballesta, M.; Dominguez-Perles, R.; Moreno, D.A.; Muries, B.; Alcaraz-López, C.; Bastías, E.; GarcíaViguera, C.; Carvajal, M, 2010. Minerals in plant food: Effect of agricultural practices and role in human health. A review. Agron. Sustain. Dev. 2010, 30, 295-309.

Mani, F., Mhamdi, M., Bettaieb, T., and Hannachi, C, 2014. Shoot regeneration, micro-propagation and microtuberization of potato (Solanum tuberosum L.) cultivars. Journal of New Sciences, 7(2):14-18.

Melkamu and Miniweyilet, 2017. Optimum rates of NPS fertilizer application for economically profitable production of potato varieties.

Minwylet, 2017. Effect of NPS fertilizer rates and irrigation frequency determination method on the growth and tuber yield of potato.

MoARD (Ministry of Agriculture and Rural Development), 2011. Animal and plant health regulatory directorate. Crop variety register issue No. 12. Addis Ababa, Ethiopia.

Moinuddin, Singh, Komal, Bansal, S.K., Pasricha, N.S, 2005. Influence of graded levels of potassium fertilizer on growth, yield, and economic parameters of potato. J. Plant Nutr. 27, 239-259.

Moreno, A., Moreno, M.M., Ribas, F. and Cabello, M.J, 2003. Influence of nitrogen fertilizer on grain yield of barley (Hordeum vulgare L.) under irrigated conditions. Spanish J.Agr. Res., 1(1): pp.91-100.

Muhammad, N., Hussain, Z., Rahmdil, \& Ahmed, N, 2015. Effect of Different Doses of NPK Fertilizes on the Growth and Tuber Yield of Potato. Life Science International Journal, 9(1, 2, 3, 4), 3098-3105.

Nasreen, S., S.M.I. Haq and M.A. Hossain, 2003. Sulfur effects on growth responses and yield of onion. Asian J. Plant Sci., 2: 897-902.

Obare, G.A.,Nyagaka，D. O., Nguyo, W. and Mwakubo, S. M, 2010. Are Kenyan smallholders allocatively efficient. Evidence from Irish potato producers in Nyandarua North district. J. Develop. Agri. Econ. 2:79.

O’brien,P.J., E.J Allen, J. N. Bean, R. L.Griffth, and J.L. Jones, 1983.Accumulated Day Degrees As A Measure Of Physiological Age and The Relationships With Growth And Yield In Early Potato Varieties. Journal of Agricultural Sciences 101: 613-631.

Oury, F.X.; Leenhardt, F.; Rémésy, C.; Chanliaud, E.; Duperrier, B.; Balfourier, F.; Charmet, G, 2006 Genetic variability and stability of grain magnesium, zinc and iron concentrations in bread wheat. Eur. J. Agron. 2006, 25, 177-185.

Pankhurst, R, 1964. Notes on history of Ethiopian agriculture. Ethiopian observer.7:pp.2.

Peter, M., Debra, K.R. and Svotwa, E, 2015.Effect of split nitrogen application and fertilizer rate on yield of Irish potatoes (Solanum tuberosum L) in a smallholder farming sector of Zimbabwe. International Journal of Innovative Science, Engineering and Technology,2(1): pp.112-123.

Pinto, E.; Almeida, A.A.; Aguiar, A.A.; Ferreira, I.M, 2015. Comparison between the mineral profile and nitrate content of microgreens and mature lettuces. J. Food Compos. Anal. 2015, 37, 38-43.

Rakshya D, and Arjun K S, 2019. Effect of Foliar Application of Zinc on Potato (Solanum Tuberosum L.) in Bhaktapur, Nepal. Agri Res\& Tech: Open Access J. 2019; 22(3): $556202 . \quad$ DOI: 10.19080/ARTOAJ.2019.22.556202.

Regmi, A., Ladha, J., Pasuquin, E., Pathak, H., \& Hobbs, P, 2002. The role of Potassium in sustaining yields in a longterm rice-wheat experiment in the Indo-Gangetic plains of Nepal. Biological Fertilizer Soils, 36, 240247.

Renata Gaj , Dariusz Górski and Leszek Majchrzak, 2020. The Effect of Potassium and Micronutrient Foliar Fertilisation on the Content and Accumulation of Microelements, Yield and Quality Parameters of Potato Tubers. Agriculture 2020, 10, 530; doi:10.3390/agriculture10110530.

Rending,V. V., and M. Taylor, 1989. Principles of soil-plant Interrelationships. Grawall-Hill publishing company, New York. pp. 87-95.

Ruža, A., Skrabule, I. and Vaivode, A, 2013. Influence of nitrogen on potato productivity and nutrient use efficiency. Proceedings of the Latvian Academy of Sciences. Section B, 67(3): pp.247-253.

Sedera, F. A., \& Shetata, S, 1994. Effect of irrigation frequency and N, K level on growth, yield, chemical composition and storage ability of potato. Zagazig Journal of Agriculture Research, 21, 129-149.

Shunka E, Chindi A, W/giorgis G, Seid E, Tessema L, 2016. Response of Potato (Solanum tuberosum L.) Varieties to Nitrogen and Potassium Fertilizer Rates in Central Highlands of Ethiopia. Adv Crop Sci Tech 4: 250. doi: $10.4172 / 2329-8863.1000250$ 
Shutian Li a, Yu Duan, Tianwen Guo, Pingliang Zhang, Ping He, Adrian Johnston, Alexey Shcherbakov, 2015. Potassium management in potato production in Northwest region of China . Field Crops Research 174 (2015) 48-54.

Sincik, M.,Turan, Z.M. and Göksoy, A.T, 2008. Responses of potato (Solanum tuberosum L.) to green manure cover crops and nitrogen fertilization rates. American Journal of Potato Research, 85: pp.150-158.

Singh, S., \& Lal, S, 2012. Effect of Potassium Nutrition on Potato Yield, Quality and Nutrient Use Effeciency Under Varied Levels Of Nitrogen Application. 39(2), 155-165.

Stol, W., Koning, G.H.J., Haverkort, A.J., Kooman, P.L., van Keulen, H. and Penning de Vries, F.W.T, 1991. Agro-ecological characterization for potato production. Asimulation study at the request of the International Potato Center (CIP), Lima, Peru.CABO-DLO, Report 155.

Subramanian, N.K.; White, P.J.; Broadley, M.R.; Ramsay, G, 2017. Variation in tuber mineral concentrations among accessions of Solanum species held in the commonwealth potato collection. Genet. Resour. Crop Ev. 2017, 64, 1927-1935.

Sud, K. C., and Sharma, R. C, 2002. Sulphur Needs of Potato under Rainfed Conditions in Shimla Hills. Potato Global Research and Development, Paul Khurana SM, Shekhawat GS, Pandey SK, Singh BS,(Eds.). Indian Potato Association, Shimla, 2, 889-899.

Syers, J.K., Johnston, A.E. and Curtin, D, 2008.Efficiency of soil and fertilizer phosphorus use. Reconciling changing concepts of soil phosphorus behavior with agronomic information. FAO fertilizer and plant nutrition bulletin No.18, Food and Agriculture Organization of the United Nations. Rome, Italy.

Tanner CB, Weis GG, Curwen D, 1982. Russet Burbank rooting in sandy soils with pans following deep ploughing. American Potato Journal59: 107-112.

Tesfaye Abebe, Asresie Hassen, Alemu Worku, Molla Tafere, Mekonen Tolla, Abel Ahmed, Seferew Dagnew, Yihenew G.Selassie and Desallegn Molla, 2015. Best fit practice manual for potato production and utilization.

Tewodros, A., Paul, C. Struik and Adane, H, 2014.Characterization of seed potato (SolanumtuberosumL.) Storage, pre-planting treatment and marketing systems in Ethiopia: thecase of west-Arsizone. African journal of agricultural research, 9(15): pp.1218-1226.

Thompson, B, 2010. Efficient fertilizer Use-Potassium (1 st edition ed.). New york: John willy and sons.

Trehan, S., Roy, S., \& Sharma, R, 2001. Potato variety differences in nutrient defeciency symptoms and responses to NPK. Better Crops International, 15, 18-21.

Tisdale,S.L., W.L. Nelson, J.D. Beaton, and J.L Halving, 1995. Soil Fertility and Fertilizers (5 ${ }^{\text {th }}$ Ed.). Macmillan Publishing Co., Inc. New York. Pp. 109-229.

Trehan, S., Roy, S., \& Sharma, R, 2001. Potato variety differences in nutrient defeciency symptoms and responses to NPK. Better Crops International, 15, 18-21.

Truog, 1946. Soil reaction influence on availability of plant nutrients. Soil Sci. Proc.11, 305-308.

Ullah and Saikia, 2008. Yield performance of processing potato varieties in the plains of Assam. Proceedings of the Global Potato Conference, Dec. 9-12, New Delhi, pp.: 22-22.

Van Den Berg, R.G. and Jacobs, M.M.J, 2007.Molecular Taxonomy. Pp. 55-76.

Vos, 1997. The nitrogen response of potato (Solanum tuberosum L.) in the field: Nitrogen up take and yield, harvest index and nitrogen concentration. Potato Research, 40: pp.237- 248.

Xu, X., He, P., Pampolino, M.F., Johnston, A.M., Qiu, S., Zhao, S., Chuan, L., Zhou, W, 2014. Fertilizer recommendation for maize in China based on yield response and agronomic efficiency. Field Crops Res. 157, 27-34.

Walter, R. and B.K. Rao, 2015. Biochars influence sweet - potato yield and nutrient uptake in tropical Papua New Guinea. J. Plant Nutr. Soil Sci., 178: 393-400.

Westennann, D, 2005. Nutritional Requirements of Potatoes. American Journal of Potato Research, 82, 301-307.

White, P.J.; Broadley, M.R.; Hammond, J.P.; Ramsay, G.; Subramanian, N.K.; Thompson, J.; Wright, G, 2012. Bio-fortification of potato tubers using foliar zinc-fertiliser. J. Hortic. Sci Biotech. 2012, 87, 123-129.

White, P.J., Wheatley, R.E., Hammond, J.P. and Zhang, K, 2007. Minerals, soils and roots. In Potato Biology and Biotechnology (pp. 739-752).

Wikipedia, 2016 Nitrogen cycle: The Free Encyclopedia. https://simple Wikipedia.Org/w/ Index.

Wild, 1988. Plant Nutrients in Soil: Phosphate. In Russell's Soil Conditions and Plant Growth, $11^{\text {th }}$ Edition, Pp. 695-742. Ed. A Wild,Lo ngman Scientific and Technical.

Zhang, K.; Greenwood, D.J.; White, P.J.; Burns, I.G, 2007. A dynamic model for the combined effects of N, P and $\mathrm{K}$ fertilizers on yield and mineral composition; description and experimental test. Plant Soil 2007, 298, 81-98. Agriculture 2020, 10, 53012 of 14 13. Roberts, T.L. Improving nutrient use efficiency. Turk. J. Agric. For. 2008, 32, 177-182. 